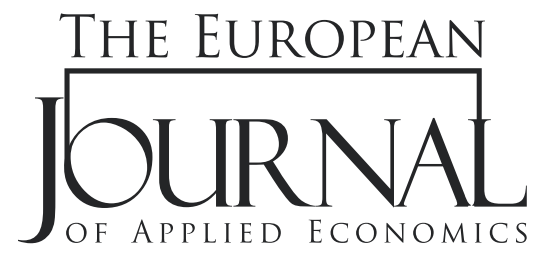

EJAE 2019, 16(1): 30-40

ISSN 2406-2588

UDK: 338.23:620.92(669)"1991/2014"

331.5.024.5:620.92

DOI: 10.5937/EJAE15-19730

Original paper/Originalni naučni rad

\title{
CAUSAL LINK BETWEEN EMPLOYMENT AND RENEWABLE ENERGY CONSUMPTION: EVIDENCE FROM NIGERIA
}

\author{
Mukhtar Wakil Lawan*, Matthew Oladapo Gidigbi
}

School of Management and Information Technology, Modibbo Adama University of Technology,

Yola, Nigeria

\begin{abstract}
:
The paper examined the causal link between employment and renewable energy consumption in Nigeria for the period of 1991 to 2014 using annual time series data. The Toda-Yamamoto Granger Causality approach was used for causal analysis and Johansen cointegration technique to verify the long-run relationship between model variables. The results supported the conservation hypothesis with unidirectional causality from employment to energy consumption, but no evidence of cointegration was established. The study recommends that Nigeria should review its energy policy in order to promote private investment in renewable energy projects towards finding a sustainable solution to help solve the energy crisis, create employment opportunities, and minimise environmental pollution peculiar to long-term use of fossil fuel.
\end{abstract}

\section{Article info:}

Received: November 30, 2018

Correction: February 8, 2019

Accepted: March 21, 2019

\section{Keywords:}

renewable,

causality,

employment,

cointegration, energy policy.

\section{INTRODUCTION}

For more than a decade, the Nigerian government has been pushing for the adaptation of renewable energy into its energy generation mix in response to the persistent energy crisis in the power sector. The existing energy policy under the Multi-Year Tariff Order (MYTO) for the power sector and existing energy laws in the petroleum industry has failed to attract the desired level of investment. The existing gas-fired power plants are largely energy inefficient, and face recurrent gas supply shortages from gas supply hubs situated in the gas-rich Niger Delta region of the country. Rising concerns and debates on the importance of environmental conservation and the reduction of air pollution, particularly from gas flaring, have also provided a strong basis for the government to propel investment in renewable energy. The government strongly believes that this strategy will also provide employment opportunities, while helping to address rising environmental concerns associated with global warming. 
Numerous earlier country-specific studies for Nigeria analysed the causality pattern between economic growth and aggregate energy/electricity consumption, and some used the traditional Granger causality approach. Therefore, this paper will contribute to the existing literature by analysing causal linkages between renewable energy consumption and employment by using the Toda-Yamamoto (1995) augmented VAR approach due to its statistical advantages over the order of integration and cointegration properties of time series.

\section{LITERATURE REVIEW}

Renewable energy sources, like solar, wind, and water, are distinct from fossil fuels due to the absence of the carbon dioxide $\left(\mathrm{CO}_{2}\right)$ gas notably identified by a number of studies (Nisbet \& Myers, 2007; Schelling, 1992; Warrick \& Farmer, 1990) as one of the green gases that contribute to global warming. Ariouri et al. (2014) have identified six economic effects that help in the understanding of the dynamic links between energy consumption and employment. The links consisted of price, substitution, democratic, structural, income, and technological effects. According to Papapetrou (2001), the price effect relates to the impact of external shocks on the prices of energy sources, like oil, gas, and coal, which can stimulate economic growth in certain economies and improve employment levels. Notable examples here are most of the OPEC member countries, which rely extensively on the export of energy resources for government revenue. The substitution effect explains how shortages or constraint in energy supply may be substituted by labour in certain macroeconomic production scenarios and vice versa. The demographic effect explains the impact of a population boom on the short-run domestic demand for energy from households, and long-run aggregate demand for energy due to changes in the level of the work-force within an economy. The structural effect describes an impact in the form of less energy consumption due to transition from manufacturing to a service-driven economy with minimal impact on unemployment. However, Jespersen (1999) argues that this might not be attainable in economies that have an energy-intensive private service sector. The income effect relates to the simultaneous growth of employment and energy consumption, which may be at different rates usually preceded by rapid economic expansion. The more income households get through employment, the higher the demand for goods, services, and subsequently energy. In terms of technological effect, Çetin and Eğrican (2011) suggest that changes from traditional energy technology to modern energy technology, such as solar energy, can create direct and indirect employment opportunities depending on a nation's development level.

Several empirical studies have tested the direction of causality between energy consumption and economic growth/employment since its introduction in Granger (1969). These studies established support for at least one of four hypotheses; conservative, growth, feedback, and neutrality hypothesis. Bilgili and Ozturk (2015) in a study of G7 countries over 1980-2009 applied panel cointegration, conventional, and dynamic OLS to establish the positive effects of biomass energy consumption on economic growth. Ocal and Aslan (2013) applied the ARDL and Toda-Yamamoto causality approach using time series covering 1990-2010 for Turkey and found evidence of causal flow from economic growth to renewable energy consumption. Kahia, Aïssa and Lanouar (2017) analysed panel data covering the period 19802012 for MENA net oil importing countries using the panel vector error correction model (PVECM). The study found evidence of simultaneous causality between economic growth and both renewable and non-renewable energy use. Payne (2009) employed the Toda-Yamamoto causality test for U.S. data for the period 1949-2006 and found no evidence of a causal link between renewable, non-renewable energy consumption, and real GDP. However, the empirical results of causal studies have mostly been mixed with no dominant prevailing theory both for the case of developed and developing countries. Awokuse (2003) and Bahmani-Oskooee and Alse (1993) have suggested that variation in causal pattern is influenced by several factors including theoretical framework, model variables, foreign policy, country specific characteristics, time period, data frequency, and methodology adopted for the causality model. 
The conservative, growth, feedback, and neutrality hypothesis are typically used to analyse the direction of causality between energy consumption and economic growth/employment. The growth hypothesis represents unidirectional causality from energy consumption to economic growth/employment. It suggests that increases in energy consumption lead to higher economic growth/employment level. A number of studies (Altinay \& Karagol, 2005; Ighodaro, 2010; Inglesi-Lotz, 2016; Ozturk \& Bilgili, 2015) found evidence in support of the growth hypothesis. The conservative hypothesis indicates a one-way link from economic growth/employment to energy consumption. It implies that higher economic growth/employment will lead to more energy consumption. The empirical findings of some studies (Lise, 2007; Matthew et al., 2018; Menyah \& Wolde-Rufael, 2010; Ocal \& Aslan, 2013; Sadorsky, 2009) supported the conservative hypothesis. The feedback hypothesis indicates a bidirectional causal link between economic growth/employment and energy consumption. Numerous studies (Apergis \& Payne, 2011; Chang et al., 2001; Ebohon, 1996; Kahia et al., 2017; Koçak \& Sarkgünes, 2017; Lin \& Moubarak, 2014; Osigwe \& Arawomo, 2015; Sebri \& Ben-Salha, 2014) established support for the feedback hypothesis. The neutrality hypothesis indicates the absence of causality in either direction between economic growth/employment and energy consumption. Some past empirical studies (Akpan \& Akpan, 2012; Esso, 2010; Menegaki \& Tugcu, 2016, 2017; Payne, 2009; Vaona, 2012) provided support for the neutrality hypothesis for the countries under study.

The use of Granger's (1969) or Sim's (1972) Granger causality approach in the early set of studies were particularly criticised due to use of non-stationary and sometimes cointegrated series. In such instances, the Wald test statistic under the null does not follow its usual asymptotic chi-square distribution. Hence, other techniques, such as the ARDL bounds testing, Johansen and Juselius (1990) cointegration technique, restricted VAR with imposed cointegration restrictions, instrumental regression, potential outcome framework, and the surplus-lag approach introduced by Toda and Yamamoto (1995) along with similar alternatives by Dolado and Lütkepohl (1996) and Bauer and Maynard (2012), were applied in later studies. The addition of surplus-lag in the causality model is meant to ensure the Wald test statistic follows its usual chi-square asymptotic null distribution in a non-stationary process. The approach also helps to minimise the pre-test bias from unit root and cointegration test at the cost of a decrease in model efficiency. Nonetheless, Clarke and Mirsa (2006) argued that the loss of power in the surplus-lag approach is less when compared to alternatives like VECM due to cointegration restrictions. The latter approach could lead to severe over-rejecting of the null hypothesis of Granger non-causality from preliminary test of cointegration. This paper focuses on analysing causal pattern, and employs the Toda-Yamamoto (1995) surplus-lag approach in the causality model.

\section{METHODOLOGY}

The study used annual time series data ${ }^{1}$ for the period 1991 to 2014 obtained from the World Development Indicators (WDI) of the World Bank for the model variables of employment (EMP) and renewable energy consumption (REC). The EMP variable expressed in percentage measures the proportion of people aged 15 and above that are employed in Nigeria, while the REC variable measures renewable energy consumption as a percentage of total final energy consumption.

\section{Order of Integration and Optimal Lag Selection}

The preliminary step for the Toda-Yamamoto (T-Y) Granger causality approach is to establish the maximum order of integration $\left(\mathrm{d}_{\max }\right)$ for model variables and the appropriate lag length $(\mathrm{k})$ for the VAR System. Hence, the order of integration for this study was established using the Augmented

1 Data set available at http://dx.doi.org/10.17632/3pp84yf7yf.1 
Dicky-Fuller (ADF) test, while the appropriate lag length (k) for the VAR system was determined using four lag selection criteria. This consisted of the Akaike Information Criterion (AIC), Schwarz Information Criterion (SC), Hannan-Quinn Information Criterion (HQ), and the Final Prediction Error (FPE).

\section{Model Diagnostic}

In order to ensure the VAR model is well specified, the serial correlation LM test is used to ensure the residuals are serially independent, and model dynamic stability is verified by analysing the inverse roots of the associated characteristic equation.

\section{Cointegration Test}

Although the cointegration test does not affect the end result of the Toda-Yamamoto Granger causality approach, the study will use the Johansen and Juselius (1990) maximum likelihood cointegration technique. This helps to provide information on the potential long-run association between model variables, and serves as a useful check for our causality model, since cointegrated variables will be expected to exhibit at least a unidirectional causal pattern. The Johansen method relies on testing the likelihood ratio of the trace test $\left(\lambda_{\text {trace }}\right)$ and max eigenvalue test $\left(\lambda_{\max }\right)$ to determine the number of cointegrating vectors for the VAR equation (1).

$$
\Delta \mathrm{Z}_{t}=\mu+\sum_{i=1}^{p-1} \Gamma_{i} \Delta \mathrm{Z}_{t-i}+\Pi \mathrm{Z}_{t-p}+\varepsilon_{t}
$$

Where $Z_{t}$ is $(n \times 1)$ vector of $\mathrm{I}(1)$ variables, $\mu$ is $(\mathrm{nx} 1)$ vector of constants, $\Gamma$ and $\Pi$ are $(\mathrm{nx} \mathrm{n})$ matrix of coefficients and parameters, $\Delta$ is difference operator, and $\varepsilon_{t}$ is $(\mathrm{n} \times 1)$ vector of error terms.

$$
\lambda_{\text {trace }}=-T \sum_{i=r+1}^{n} \ln \left(1-\lambda_{i}\right)
$$

Where $\mathrm{T}$ stands for the number of observations usable, $\mathrm{Ln}$ is natural $\log$, and $\lambda$ is characteristic root estimated (eigenvalue). The trace test in equation (2) test the null hypothesis that the rank of $\Pi$ is less than or equal to $r$ cointegrating vector(s).

$$
\lambda_{\max }=-T \ln \left(1-\lambda_{i}\right)
$$

The max eigenvalue test in equation (3) test the null hypothesis for the presence of exactly $r$ cointegrating vectors in $\mathrm{Z}_{\mathrm{t}}$ in the VAR equation (1).

\section{Granger Causality Model}

The Granger causality model is based on the Toda-Yamamoto (1995) approach. The causal test follows a standard asymptotic distribution for the Wald statistic regardless of the order of integration and cointegration between model variables (Bosupeng, 2016). The Granger non-causality model is expressed in equation (4) and (5). 


$$
\begin{aligned}
& E M P_{t}=\delta_{1}+\sum_{i=1}^{k+d \max } \Psi_{1 i} E M P_{t-1}+\sum_{i=1}^{k+d \max } \lambda_{1 i} R E C_{t-1}+\mu_{1 t} \\
& R E C_{t}=\delta_{2}+\sum_{i=1}^{k+d \max } \Psi_{2 i} R E C_{t-1}+\sum_{i=1}^{k+d \max } \lambda_{2 i} E M P_{t-1}+\mu_{2 t}
\end{aligned}
$$

In equations (4-5), $\delta, \psi$ and $\lambda$ are model parameters and $\mathrm{k}$ is the appropriate lag length while $\mathrm{d}_{\max }$ is maximum integration order. The symbol $\mu_{t}$ is model uncorrelated error term while EMP and REC stand for variables of employment and renewable energy consumption respectively.

\section{EMPIRICAL RESULTS AND DISCUSSION}

\section{Unit Root Test and Optimal Lag Selection Results}

The results of the unit root test for determining the order of integration for variables of employment (EMP) and renewable energy consumption (REC) based on the ADF test is shown in table 1.

\begin{tabular}{cccccc}
\hline Variables & Level & $\begin{array}{c}\mathbf{5 \%} \text { Critical } \\
\text { Value }\end{array}$ & First Difference & $\begin{array}{c}\mathbf{5 \%} \text { Critical } \\
\text { Value }\end{array}$ & Remark \\
\hline EMP & -1.59 & -2.99 & $-3.38^{*}$ & -3.00 & $\mathrm{I}(1)$ \\
\hline REC & -2.34 & -2.99 & $-5.37^{*}$ & -3.00 & $\mathrm{I}(1)$ \\
\hline
\end{tabular}

Note: ${ }^{*}$ denotes null rejection of non-stationarity at $5 \%$ level

Table 1. Augmented Dickey-Fuller (ADF) Unit Root Test Results

The results in table 1 suggest that the variables of renewable energy consumption (REC) and employment (EMP) are both stationary after first differencing and thus, maximum order of integration $\left(\mathrm{d}_{\max }\right)$ is 1 . This also fulfils the condition to check for the presence of cointegration between the two variables.

\begin{tabular}{ccccc}
\hline Lag & FPE & AIC & SC & HQ \\
\hline 0 & 0.086287 & 3.225445 & 3.324375 & 3.239086 \\
\hline 1 & $0.037757^{*}$ & $2.392903^{*}$ & $2.689694^{*}$ & $2.433827^{*}$ \\
\hline 2 & 0.047615 & 2.601179 & 3.095830 & 2.669384 \\
\hline 3 & 0.050764 & 2.608780 & 3.301291 & 2.704268 \\
\hline 4 & 0.077526 & 2.921383 & 3.811755 & 3.044153 \\
\hline 5 & 0.089162 & 2.860121 & 3.948353 & 3.010174 \\
\hline
\end{tabular}

Note: * indicates lag order selected by each criterion

Table 2. VAR Lag Order Selection Results

The appropriate lag length $(\mathrm{k})$ for the VAR causality model based on the four information criteria is lag 1 as shown in table 2 results. The model is also found to be dynamically stable and the residuals serially independent. Hence, the optimal lag for the Granger causality model, VAR $\left(k+d_{\max }\right)$ is 2 . 


\section{Model Diagnostic Test Results}

The result of the serial correlation LM test is shown in table 3 and the inverse roots of the characteristic equation is shown in figure 1.

\begin{tabular}{ccccc}
\hline Lag & LRE $^{\star}$ stat & Prob. & Rao F-stat & Prob. \\
\hline 1 & 6.719831 & 0.1515 & 1.825352 & 0.1520 \\
\hline 2 & 0.525369 & 0.9710 & 0.127969 & 0.9710 \\
\hline 3 & 0.981194 & 0.9126 & 0.240892 & 0.9127 \\
\hline 4 & 3.255813 & 0.5160 & 0.831700 & 0.5164 \\
\hline 5 & 5.162243 & 0.2711 & 1.363847 & 0.2716 \\
\hline 6 & 3.279710 & 0.5122 & 0.838156 & 0.5126 \\
\hline
\end{tabular}

Note: * Edgeworth expansion likelihood ratio statistic

Table 3. VAR Residual Serial Correlation LM Test

The results in table 3 indicates that serial correlation is removed from the model at $5 \%$ level.

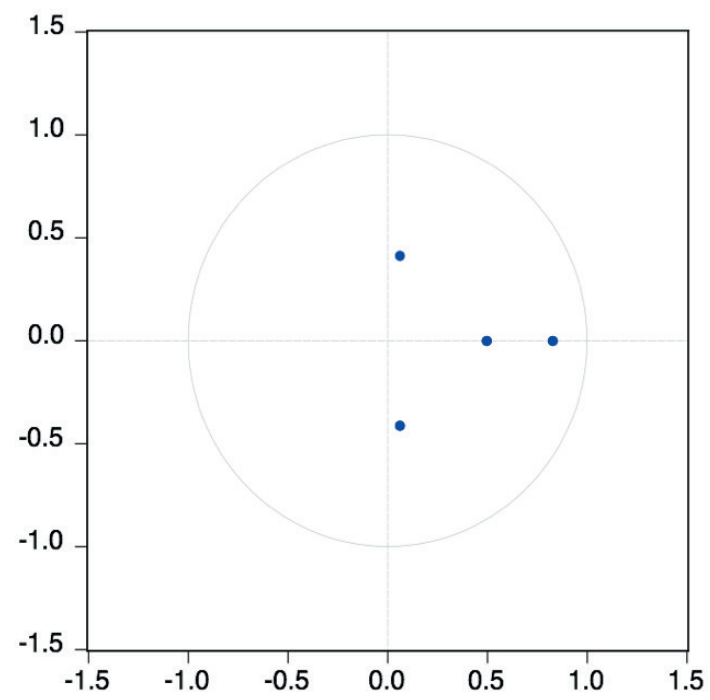

Figure 1. Inverse Roots of AR characteristic Polynomial

The results in figure 1 established that the VAR model is dynamically stable as all points lie within the unit circle.

\section{Cointegration Test Results}

The results of the Johansen cointegration test for the two I(1) model variables are shown in table 4. 


\begin{tabular}{cccccccc}
\hline \multirow{2}{*}{ Vector } & & $\begin{array}{c}\text { Trace } \\
\text { Statistics }\end{array}$ & $\begin{array}{c}\text { Critical } \\
\text { Value }\end{array}$ & Probability & $\begin{array}{c}\text { Max-Eigen } \\
\text { Statistics }\end{array}$ & $\begin{array}{c}\text { Critical } \\
\text { Value }\end{array}$ & Probability \\
\hline $\mathrm{H}_{\mathrm{o}}$ & $\mathrm{H}_{1}$ & $\lambda_{\text {trace }}$ & $5 \%$ & $\mathrm{P}$ & $\lambda_{\max }$ & $5 \%$ & $\mathrm{P}$ \\
\hline $\mathrm{r}=0$ & $\mathrm{r}>0$ & 12.22 & 15.49 & 0.15 & 10.26 & 14.26 & 0.20 \\
\hline $\mathrm{r}<=1$ & $\mathrm{r}>1$ & 1.97 & 3.84 & 0.16 & 1.97 & 3.84 & 0.16 \\
\hline
\end{tabular}

Note: $\mathrm{r}$ indicates number of cointegrating vector $(\mathrm{s})$

Table 4. Johansen Cointegration Test Results

The trace and Max-Eigen statistics in table 4 indicate the absence of cointegration between the two variables of REC and EMP. The null hypothesis of no cointegration cannot be rejected at the 5\% significance level. The absence of cointegration over the study period lend credence to the energy policy in Nigeria that has promoted investment in the petroleum sector to sustain the economy through revenue generation and employment. As a result, most studies (Akpan \& Akpan, 2012; Ighodaro, 2010; Matthew et al., 2018) for Nigeria that used electricity as proxy for energy consumption found evidence of longrun relationship with economic growth. A further emphasis on the dominant use of non-renewables (particularly natural gas) in power generating plants for several decades across the country.

\section{Granger Causality Test Results}

The results of the Granger non-causality model using the set of equations (4-5) in the augmented level VAR $\left(\mathrm{k}+\mathrm{d}_{\max }\right)$ for the Wald test is shown in table 5.

\begin{tabular}{lcc}
\hline & EMP & REC \\
\hline EMP & - & $5.54^{*}(0.019)$ \\
\hline REC & $0.082(0.77)$ & - \\
\hline
\end{tabular}

Note: * denotes null rejection of Granger non-causality at $5 \%$ level

Probability reported in parenthesis

Table 5. T-Y Granger Non-Causality Test Results

The results in table 5 indicate a one-way causality from employment (EMP) to renewable energy consumption (REC) as the null hypothesis of Granger non-causality is rejected at 5\% level. It implies that renewable energy consumption will continue to rise so long as employment levels continue to grow in Nigeria. Hence, execution of renewable energy projects towards power generation will help to create both direct and indirect employment which should induce an income effect, technological effect and lead to higher energy consumption in the Nigerian economy. Direct jobs can be created in the short-term during construction due to building, procurement, and installation of equipment at renewable based power stations. Likewise, additional jobs are created during the course of operation and maintenance of power stations in the long-term. Indirect jobs can be created during the course of transmission and distribution of electrical power. These employment opportunities will increase the potential for household spending on goods and services, which will have to be compensated by higher energy consumption, especially by firms, in order to meet those demands.

The causal pattern observed in this paper differs from the findings of other studies (Akpan \& Akpan, 2012; Ebohon, 1996; Esso, 2010; Ighodaro, 2010; Osigwe \& Arawomo, 2015) for Nigeria largely due to 
variation in methodological approach. The unrestricted test adopted in this paper minimise the prefiltering bias likely to affect some of those papers. However, this study is limited by the availability of data on renewable energy consumption, thereby limiting the time period for the causal analysis which could also account for variation in outcomes across these set of related studies.

\section{CONCLUSION AND POLICY RECOMMENDATION}

The study used annual time series data for the period 1991-2014 to analyse the causal pattern between employment and renewable energy consumption in Nigeria. The Toda-Yamamoto Granger non-causality technique was employed for the causality model, and the Johansen cointegration technique was used to check for the long-run relationship between model variables.

The findings support the conservative hypothesis as a one-way causal link was found from employment to renewable energy consumption in Nigeria for the period under consideration. As a result, employment can be created during the construction phase and in the long-run during operations and maintenance of renewable energy projects. This will result in higher supply and consumption of energy by residential consumers and firms. Due to the large abundance of reserve for conventional energy sources in Nigeria, the energy policy has mostly been geared towards promoting investment in infrastructure to harness oil and gas resources. However, rising population figures, oil price volatility, and air pollution, particularly from gas flaring in the oil industry, necessitates finding an economic and environmentally sustainable solution to the energy crisis, and unemployment through the adaptation of renewable energy resources. The energy crisis that has persisted for several decades has led to the collapse of many industries and business enterprises, resulting in alarming levels of unemployment figures.

The study recommends that policy makers should introduce incentives such as import duty exemption and a tax holiday in order to propel private investment in renewables particularly in the powergenerating segment of the economy. Longe et al. (2018) established evidence of positive short-run and long-run relationship between carbon dioxide emissions and energy use pattern in Nigeria. Diversification into renewables will provide employment opportunities, particularly in the rural areas, and eliminate the health-related costs associated with air pollution notable with the use of carbon-rich fossil fuels.

Furthermore, small and medium scale local production of alternative vehicle fuels, such as biodiesel, should be supported by energy policy in Nigeria. The Nigerian Electricity Regulatory Commission (NERC) should seek to introduce and implement a feed-in tariff scheme in order to facilitate the adaptation of renewables and reduce the perceived producer economic risk in renewable energy production. It is widely believed that Nigeria, like many oil producing countries, has passed its peaked oil production and, as such, it is imperative the country exploit its vast renewable energy resources in order to sustain economic growth going into the future. Lastly, policymakers should seek to implement a strategic plan towards ensuring that new and existing hydropower plants are well equipped with modern technology in order to facilitate energy efficiency, and create employment in the combined effort towards promoting an eco-friendly environment.

Although the findings are meant to complement other empirical studies on the causal link between employment and energy consumption for Nigeria, there are still ways to expand on the research in further studies. One such way is to disaggregate renewable energy consumption into its different components leading to a multivariate causality model, which can provide further insight on the source of renewable energy that exacts greater employment effects on the economy. Moreover, another methodology other than the surplus-lag approach, such as the bootstrapped p-value, could potentially be used to improve the efficiency of the Granger non-causality test. 


\section{REFERENCES}

Akpan, G. E., \& Akpan, U. F. (2012). Electricity Consumption, Carbon Emissions and Economic Growth in Nigeria. International Journal of Energy Economics and Policy, 2(4), 292-306.

Altinay, G., \& Karagol, E. (2005). Electricity Consumption and Economic Growth: Evidence from Turkey. Energy Economics, 27, 849-856.

Apergis, N., \& Payne, J. E. (2011). The Renewable Energy Consumption - Growth Nexus in Central America. Applied Energy, 88(1), 343-347. DOI:10.1016/j.apenergy.2010.07.013

Arouri, M. E. H., Youseff, A.B., M'Henni, H., \& Rault, C. (2014). Exploring the Causality Links between Energy and Employment in African Countries. IZA Discussion Paper No. 8296. Retrieved from http://anon-ftp. iza.org/dp8296.pdf

Awokuse, T. O. (2003). Is the Export-led Growth Hypothesis Valid for Canada? The Canadian Journal of Economics / Revue Canadienne d'Economique, 36(1), 126-136. DOI:10.1111/1540-5982.00006

Bahmani-Oskooee, M., \& Alse, J. (1993). Export growth and Economic growth: An Application of Cointegration and Error-correction Modelling. The Journal of Developing Areas, 27(4), 535-542.

Bauer, D., \& Maynard, A. (2012). Persistence-robust Surplus-lag Granger Causality Testing. Journal of Econometrics, 169(2), 293-300. DOI:10.1016/j.jeconom.2012.01.023

Bilgili, F., \& Ozturk, I. (2015). Biomass Energy and Economic Growth Nexus in G7 countries: Evidence from Dynamic Panel Data. Renewable and Sustainable Energy Reviews, 49, 132-138. DOI:10.1016/j.rser.2015.04.098

Bosupeng, M. (2016). Adverse Effects of the Automotive Industry on Carbon Dioxide Emissions. The European Journal of Applied Economics, 13(1), 1-12. DOI:10.5937/ejae13-9345

Çetin, M., \& Eğrican, N. (2011). Employment Impacts of Solar Energy in Turkey. Energy Policy, 39(11), 71847190. DOI:10.1016/j.enpol.2011.08.039

Chang, T., Fang, W., \& Wen, L. (2001). Energy Consumption, Employment, Output, and Temporal Causality: Evidence from Taiwan Based on Cointegration and Error-Correction Modelling Techniques. Applied Economics, 33(8), 1045-1056. DOI:10.1080/00036840122484

Clarke, J. A., \& Mirza, S. (2006). A Comparison of Some Common Methods for Detecting Granger Noncausality. Journal of Statistical Computation and Simulation, 76(3), 207-231. DOI:10.1080/10629360500107741

Dolado, J., \& Lütkepohl, H. (1996). Making Wald Tests Work for Cointegrated VAR Systems. Econometric Reviews, 15(4), 369-386. DOI:10.1080/07474939608800362

Ebohon, O. J. (1996). Energy, Economic Growth and Causality in Developing Countries: A Case Study of Tanzania and Nigeria. Energy Policy, 24(5), 447-453. DOI:10.1016/0301-4215(96)00027-4

Esso, L. J. (2010). Threshold Cointegration and Causality Relationship Between Energy Use and Growth in Seven African Countries. Energy Economics, 32(6), 1383-1391. DOI:10.1016/j.eneco.2010.08.003

Granger, C. W. J. (1969). Investigating Causal Relations by Econometric Models and Cross-spectral Methods. Econometrica, 37(3), 424-438. DOI:10.2307/1912791

Ighodaro, C. A. U. (2010). Co-Integration and Causality Relationship between Energy Consumption and Economic Growth: Further Empirical Evidence for Nigeria. Journal of Business Economics \& Management, 11(1), 97-111. DOI:10.3846/jbem.2010.05

Inglesi-Lotz, R. (2016). The Impact of Renewable Energy Consumption to Economic Growth: A Panel Data Application. Energy Economics, 53, 58-63. DOI:10.1016/j.eneco.2015.01.003

Jespersen, J. (1999). Reconciling Environment and Employment by Switching from Goods to Services? A Review of Danish Experience. European Environment, 9(1), 17-23. DOI:10.1002/(SICI)1099-0976 (199901/02)9:1<17::AID-EET180>3.0.CO;2-J

Johansen, S., \& Juselius, K. (1990). Maximum Likelihood Estimation and Inference on Cointegration - With Applications to the Demand for Money. Oxford Bulletin of Economics and Statistics, 52(2), 169-210. 
Kahia, M., Aïssa, M. S. B., \& Lanouar, C. (2017). Renewable and Non-renewable Energy use - Economic growth Nexus: The Case of MENA Net Oil Importing Countries. Renewable and Sustainable Energy Reviews, 71, 127-140. DOI:10.1016/j.rser.2017.01.010

Koçak, E., \& Şarkgüneşi, A. (2017). The Renewable Energy and Economic Growth Nexus in Black Sea and Balkan Countries. Energy Policy, 100, 51-57. DOI:10.1016/j.enpol.2016.10.007

Lin, B., \& Moubarak, M. (2014). Renewable Energy Consumption - Economic Growth Nexus for China. Renewable and Sustainable Energy Reviews, 40, 111-117. DOI:10.1016/j.rser.2014.07.128

Lise, W., \& Van Montfort, K. (2007). Energy Consumption and GDP in Turkey: Is there a Co-Integration Relationship? Energy Economics, 29(6), 1166-1178. DOI:10.1016/j.eneco.2006.08.010

Longe, A. E., Ajulo, K. D., Omitogun, O., \& Adebayo, E. O. (2018). Trade, Transportation and Environment Nexus in Nigeria. The European Journal of Applied Economics, 15(2), 29-42. DOI:10.5937/EJAE15-17360

Matthew, O. A., Ede, C. U., Osabohien, R., Ejemeyovwi, J., Fasina, F. F., \& Akinpelumi, D. (2018). Electricity Consumption and Human Capital Development in Nigeria: Exploring the Implications for Economic Growth. International Journal of Energy Economics and Policy, 8(6), 8-15. DOI:10.32479/ijeep.6758

Menegaki, A. N., \& Tugcu, C. T. (2016). Rethinking the Energy-Growth Nexus: Proposing an Index of Sustainable Economic Welfare for Sub-Saharan Africa. Energy Research \& Social Science, 17, 147-159. DOI:10.1016/j. erss.2016.04.009

Menegaki, A. N., \& Tugcu, C. T. (2017). Energy Consumption and Sustainable Economic Welfare in G7 Countries; A Comparison with the Conventional Nexus. Renewable and Sustainable Energy Reviews, 69, 892-901. DOI:10.1016/j.rser.2016.11.133

Menyah, K., \& Wolde-Rufael, Y. (2010). CO2 Emissions, Nuclear Energy, Renewable Energy and Economic Growth in the Us. Energy Policy, 38, 2911-2915. DOI:10.1016/j.enpol.2010.01.024

Nisbet, M. C., \& Myers, T. (2007). Trends: Twenty Years of Public Opinion About Global Warming. The Public Opinion Quarterly, 71(3), 444-470.

Ocal, O., \& Aslan, A. (2013). Renewable Energy Consumption-Economic Growth Nexus in Turkey. Renewable and Sustainable Energy Reviews, 28, 494-499. DOI:10.1016/j.rser.2013.08.036

Osigwe, A. C., \& Arawomo, D. F. (2015). Energy Consumption, Energy Prices and Economic Growth: Causal Relationships based on Error Correction Model. International Journal of Energy Economics and Policy, 5(2), 408-414.

Ozturk, I., \& Bilgili, F. (2015). Economic Growth and Biomass Consumption Nexus: Dynamic Panel Analysis for Sub-Sahara African Countries. Applied Energy, 137, 110-116. DOI:10.1016/j.apenergy.2014.10.017

Papapetrou, E. (2001). Oil Price Shocks, Stock Market, Economic Activity and Employment in Greece. Energy Economics, 23(5), 511-532. DOI:10.1016/S0140-9883(01)00078-0

Payne, J. E. (2009). On the Dynamics of Energy Consumption and Output in the US. Applied Energy, 86, 575-577. DOI:10.1016/j.apenergy.2008.07.003

Sadorsky, P. (2009). Renewable Energy Consumption and Income in Emerging Economies. Energy Policy, 37(10), 4021-4028. DOI:10.1016/j.enpol.2009.05.003

Schelling, T. C. (1992). Some Economics of Global Warming. The American Economic Review, 82(1), 1-14.

Sebri, M., \& Ben-Salha, O. (2014). On the Causal Dynamics between Economic Growth, Renewable Energy Consumption, CO2 Emissions and Trade Openness: Fresh Evidence from BRICS Countries. Renewable and Sustainable Energy Reviews, 39, 14-23. DOI:10.1016/j.rser.2014.07.033

Sims, C. A. (1972). Money, Income and Causality. American Economic Review, 62(4), 540-552.

Toda, H. Y., \& Yamamoto, T. (1995). Statistical Inference in Vector Autoregressions with Possibly Integrated Processes. Journal of Econometrics, 66(1-2), 225-250. DOI:10.1016/0304-4076(94)01616-8

Vaona, A. (2012). Granger Non-Causality Tests between (Non)Renewable Energy Consumption and Output in Italy Since 1861: The (Ir)Relevance of Structural Breaks. Energy Policy, 45, 226-236. DOI:10.1016/j.enpol.2012.02.023

Warrick, R., \& Farmer, G. (1990). The Greenhouse Effect, Climatic Change and Rising Sea Level: Implications for Development. Transactions of the Institute of British Geographers, 15(1), 5-20. DOI:10.2307/623089 


\section{UZROČNA VEZA IZMEĐU ZAPOŠLJAVANJA I POTROŠNJE OBNOVLJIVE ENERGIJE: PRIMER NIGERIJE}

\section{Rezime:}

Rad je ispitao uzročnu vezu između zapošljavanja, s jedne strane i potrošnje energije iz obnovljivih izvora, s druge strane - u Nigeriji, za period 1991-2014. godine, a oslanjajući se na godišnje podatke o vremenskim serijama. Pristup Toda-Yamamoto Granger je korišćen za uzročnu analizu, a Johansen tehnika kointegracije je upotrebljena da bi se potvrdila dugoročna veza između varijabli modela. Rezultati su podržali hipotezu o očuvanju jednosmerne uzročnosti između zapošljavanja i potrošnje energije, ali nije utvrđen nikakav dokaz o kointegraciji. Studija preporučuje da Nigerija treba da analizira svoju energetsku politiku, kako bi promovisala privatna ulaganja u projekte obnovljivih izvora energije u pronalaženju održivog rešenja u vezi sa energetskom krizom, kao i stvaranju mogućnosti za zapošljavanje i smanjenju zagađenja životne sredine, koji karakterišu dugoročnu upotrebu fosilnih goriva.

\section{Ključne reči:}

obnovljiva energija, uzročnost, zaposlenje, kointegracija, energetska politika. 